\title{
INNOVATION FOR INCLUSIVE DEVELOPMENT: MAPPING AND AUDITING THE USE OF ICTS IN THE SOUTH AFRICAN PRIMARY EDUCATION SYSTEM
}

\author{
P. Hove ${ }^{1}$ \& S.S. Grobbelaar ${ }^{2,3 *}$
}

\section{ARTICLE INFO}

\section{Article details}

Submitted by authors $\quad 18$ Apr 2019 Accepted for publication 21 Feb 2020 Available online 29 May 2020

\section{Contact details}

Corresponding author ssgrobbelaar@sun.ac.za

Author affiliations

1 Graduate School of Technology Management

University of Pretoria, South Africa

2 Department of Industrial Engineering, Stellenbosch University, South Africa

3 DST-NRF CoE in Scientometrics and Science, Technology and Innovation Policy, Stellenbosch University, South Africa

\section{DOI}

http://dx.doi.org/10.7166/31-1-2119

\section{ABSTRACT}

Inclusive education aims to identify and minimise barriers to learning and maximise learner participation in the education system. With a focus on the use of information and communication technologies in the South African primary education system, this study aims 1) to create a framework with which to evaluate the current state of ICT uptake across core functions for a school; 2) to audit the current state of innovation uptake; 3 ) to use the audit outcomes to identify challenges to the uptake of ICTs; and 4) to identify measures for facilitating an improved uptake of these innovations. The researchers conclude that a need exists for government to ensure consistent ICT uptake and use throughout the education system through a better implementation of standards, policies, and processes that facilitate technology uptake.

\section{OPSOMMING}

Inklusiewe onderrig beoog om struikelblokke tot onderrig te identifiseer en te minimeer en om leerderdeelname te maksimeer. Met die fokus op die gebruik van informasie- en kommunikasietegnologieë in die Suid-Afrikaanse basiese onderwysstelsel, is hierdie studie gerig op 1) die skep van 'n raamwerk waarmee die huidige toestand van die opname van informasieen kommunikasietegnologie, vir die kernfunksies van 'n skool, bepaal kan word; 2) om die huidige toestand van innovasie opname te oudit; 3 ) om die oudituitkomste te gebruik om uitdagings te identifiseer; en 4) om maatstawwe, wat 'n verbeterde opname van hierdie tegnologieë kan fasiliteer, te identifiseer. Die navorsers het tot die gevolgtrekking gekom dat daar ' $n$ behoefte bestaan wat vereis dat die regering seker moet maak dat konsekwente inligting- en kommunikasietegnologie opname regdeur die onderwysstelsel geskied. Dit is moontlik deur 'n verbeterde implementering van standaarde, beleide, en prosesse wat tegnologieopname fasiliteer.

\section{INTRODUCTION AND PROBLEM STATEMENT}

Although some view inclusive education as an approach that includes and serves children with disabilities, it has also been viewed as an approach that increases diversity among learners. In this sense, inclusive education aims to identify and minimise barriers to learning and to maximise learner participation and involvement in the education system [1], [2]. Inclusion, for the purpose of this article, is defined as a process of strengthening the capacity of the education system to reach out to all citizens, with its main goal being to guide education policies and practices based on the belief that education is a basic human right and the foundation of an equal society [2]-[4].

The South African education system has some measures in place to facilitate inclusion in primary education. For instance, The South African Schools Act (SASA) of 1996 aims to ensure that every child has access to education and is not subject to discrimination [4]. Schooling is compulsory for children aged 7 to 15 , and any child can enrol at a public school free of charge, which means that poor learners should also have access to education. The South African education policy on religion and culture in public education stipulates that religious, political, and ethnic background should not hinder inclusion in schools [5]. 
However, the general quality of primary education in South Africa remains poor; in 2015 the Organisation for Economic Co-operation and Development (OECD) found that, among the 76 countries evaluated, South Africa's education system was performing second-worst [6]. And for primary school learners specifically, Spaull found that these learners had not reached standard literacy and numeracy milestones, with a national average of $30-35 \%$ on numeracy and literacy tests [7]. The system is also characterised by huge inequalities and inequities: many historically disadvantaged schools suffer poor resourcing, while many historically advantaged schools enjoy good resourcing and management, and are better able to equip learners to do well in exams [7].

Information and communication technologies (ICTs) have long been recognised by the South African Government to have the potential to improve the delivery of quality education for all. The South African education ICT white paper [8] states the following:

"Learning through the use of ICTs is arguably one of the most powerful means of supporting learners to achieve the nationally stated curriculum goals. In particular, the use of ICTs for learning encourages: learner-centred learning; active, exploratory, inquiry-based learning; collaborative work among learners and teachers; and creativity, analytical skills, critical thinking and informed decision-making.

It also states [8]:

"As with other types of organisations, schools and school systems are increasingly using management information systems for planning, monitoring, improvement and accountability purposes. ICTs have the capacity to automate processes and save time, thereby freeing managers to focus on instructional leadership"

ICTs can thus be argued to be the basis for innovations that can be employed in the primary education system [9]. ICTs are not only the backbone of the information society, but are an important catalyst for bringing about educational reforms that can transform learners into productive knowledge users. ICTs can support activities such as reporting systems, the effective management of schools, and teaching activities [10]. If some school management functions can be supported by ICTs, it means that the workload of educators could be reduced, allowing them the opportunity to focus more on learners. ICTs can enable inclusion if they assist in addressing and responding to the different needs of all children through increasing their involvement or participation in education, and by reducing or eliminating exclusions in the education system [12].

The adoption of an innovation can be defined as the integration of new technology into the end-users' daily lives [11]. Adoption begins when a person moves from being unaware of a certain solution to being aware of available or introduced innovations [12]. The literature tells us that innovations can be adopted if they are easy to use, observable, better than existing systems, and compatible with users' norms and values, thereby promoting inclusion [13], [14]. If the innovation is not compatible with current systems, it means that users will be overburdened trying to make use of it, and may need a lot of time to resume their daily work tasks, which, in turn, may inhibit its adoption [11]. One might expect that many schools in South Africa would be likely to have difficulties in adopting ICTs due to, inter alia, a lack of adequate computer literacy, IT management skills, enabling infrastructure, and funding [15].

This research article therefore attempts to achieve the following objective: to develop an innovation for an inclusive development auditing framework for the South African primary education system that supports a better understanding of the state of uptake of ICTs across core functions. This is then intended to be used to inform strategies that will help to improve access to education through the use of ICTs.

In order to achieve this objective, the authors answer the following research questions:

- What is the current state of the adoption of ICTs at the primary school level in South Africa?

- What challenges does the South African Government face in the implementation of ICTs for inclusive innovation in education?

- What measures could be implemented to facilitate improved ICT adoption in the South African primary education system? 
Everett Rogers [16], the leading scholar in the diffusion-of-innovations paradigm, uses 'diffusion' to refer to the spread of innovations. An innovation is "an idea, practice or object that is perceived as new by an individual or other unit of adoption" [16] and innovation diffusion is the "process by which (1) an innovation is (2) communicated through certain (3) channels over time among the members of (4) a social system". Since the development of these ideas in the 1930 s by rural sociologists in the United States, a large literature has developed on the process and modelling of the development and diffusion of innovations. In parallel with this, concepts such as 'technology transfer' refer to the transfer of technical know-how, information, and people among technical functions in firms to yield innovative service and products that meet the strategic needs of a business and a customer.

These ideas remain relevant in the area of innovation for inclusive development. However, it is a widely held view that, although innovation is highly correlated with economic growth, the lack of access to innovation may cause inequality. There is a growing body of literature that explores how the innovation process can be adapted to support inclusive development [17]-[20]. This has led to the development of concepts such as 'social innovation', 'inclusive innovation', 'innovation for inclusive growth' [21], and 'innovation for inclusive development' [22]. These alternative innovation models regard marginalised communities not only as potential customers, but also as business partners who could be included in the innovation process so that they could ultimately benefit economically from the resulting innovations [21]. This requires a whole new group of participants in the innovation process [23], [24], which has complex dynamics and is beyond the scope of this article. The aim of this study is not to consider the process and dynamics of the development and diffusion of innovation for inclusive development, but rather to provide a basis to review the state of uptake of ICTs in the primary education system of South Africa. In order to facilitate this process, a framework has had to be developed to map the core functions of a school. For this reason, we do not include core theories of the diffusion of innovations in this study, but rather develop a tool to get a 'snapshot' of the uptake.

The value chain model, originally developed by Porter [25], has in previous studies provided a useful framework for analysing potential application areas and adoption options for ICTs in the education value chain [26], [27]. A value chain is a framework that describes a full range of activities that firms and workers perform to bring a product from its design to end-use and beyond [28]. In the education sector, the value chain framework has been applied in a wide range of higher education contexts [26], [29].

In the primary education area, we adopt the value chain framework from Perumal [28] to include primary activities and supporting activities for a primary school. The framework model depicts activities such as teacher recruitment, learner enrolment, and the management of schools, which are typical primary school activities. Figure 1Error! Reference source not found. shows the primary school activities mapped on to the familiar value chain framework. The framework looks at primary support services such as technology, teacher support and development, administration and management, and procurement. The secondary support services identified are human resources and school infrastructure.

Referring back to the original value chain framework, inbound logistics in the education framework refers to funds, teacher recruitment, and learner enrolments. Operations refers to school activities such as teaching, learning, and assessment, as well as school administration and management. Outbound logistics can be linked to having literate learners in schools and better skilled and empowered educators. Marketing and sales refers to the way the schools will be making the services on offer known to communities. For example, school websites can contain information about activities and results. The schools can also use their website and social media to advertise for enrolment and to communicate extramural activities. Services includes reporting and managing school funds and assets. 


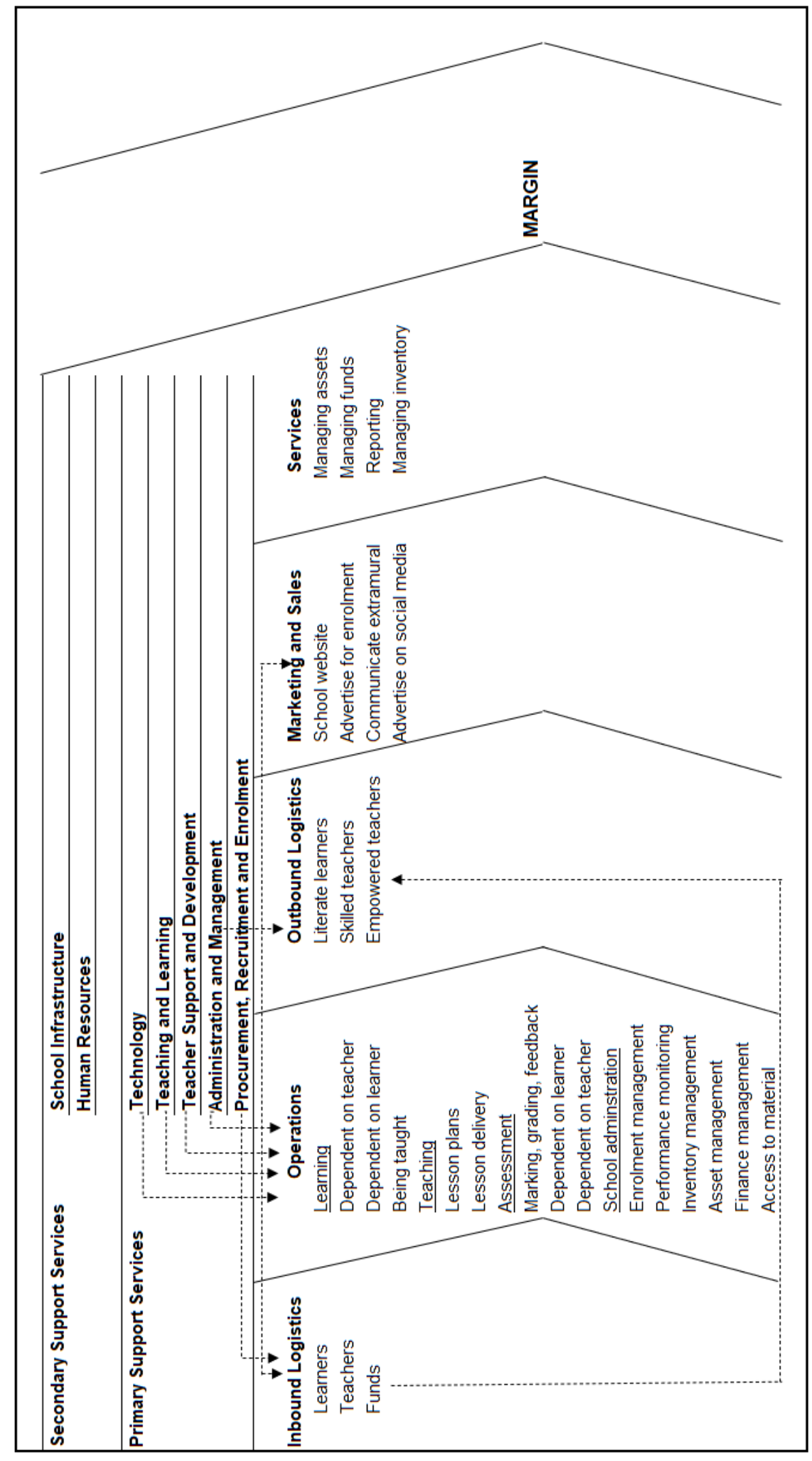

Figure 1: The primary education value chain framework 
In order to apply the above framework to the use of ICTs in education, the authors identified some schoollevel programmes that can be supported by ICTs in primary school administration (see Table 1) [28]. The authors therefore identified the systems that can be used to support different administration activities:

- A learner enrolment management system provides a platform for learner registration and updated details for reporting purpose. A performance monitoring system provides the management and responsible authorities with the basis on which to monitor and evaluate learner performance based on the cumulative results in the system. Whenever learner performance is monitored, it helps the decision-makers to decide whether remedial classes or extra lessons need to be conducted, thereby improving the learning process. Knowledge gaps in the educators can also be identified, which can help the education system to develop its educators through in-service training [31].

- The inventory/asset management system can be used to keep records of school resources such as textbooks, school nutrition programme data, furniture, and all other assets. This system can help to provide information about the available resources compared with the available users to benchmark across schools, and to ensure that they are optimally applied. It can also support school management in their procurement function.

- A school management system can help management and the responsible authorities to keep track of all school-related functions, thus promoting teaching and learning in schools. It can also help to automate some of the schools' activities and so improve the ways in which schools are managed. This will further increase time for teaching and learning, since educators will be free from many administrative duties if they are automated.

In general, ICTs enable communication in organisations through the use of e-mail and social media, the internet, SMSs, and phone calls [32]. They also provide an important tool for bringing about educational reforms [33]. In order for an innovation to be adopted, users tend to compare the benefits of a new system with their current system. Even though the benefits of ICT in primary education may lead to reduced time to access information, reduced costs due to reduced paper work, ease of information access and retrieval, and quick communication, the way users will experience the system and the change management required to shift to electronic systems may prove to inhibit its adoption.

\section{RESEARCH METHOD OR APPROACH}

In order to test and apply the developed auditing framework and tool, this research project surveyed 20 primary schools, selecting them through a stratified random sampling technique from both urban and rural areas of Gauteng Province. The definition of 'urban' and 'rural' rests on the StatsSA definition, which draws on various indicators, mostly depending on population density [34]. According to the School Act of South Africa [35], two categories of schools are recognised: public and independent. All private schools fall into the 'independent' category, while public schools are state-controlled. Given the difference in resourcing that schools often experience, and the digital divide that exists between them, this study aims to take these into account in our interpretation of the findings by distinguishing between rural and urban and private and public schools. Respondents targeted in the survey were schools' principals, deputy principals, and school managers, since they are involved in the day-to-day management of schools. This enhances validity and reliability, which are critical measures to determine the credibility, truthfulness, and believability of research findings [36].

The surveys were structured so that, in some cases, open-ended questions were used to acquire more detailed information. The questionnaires were sent to the selected respondents to survey whether their school was already making use of ICTs. The survey asked the respondents to identify the different ways in which ICTs were being used in their schools, and also to explore the benefits and challenges associated with the use of ICTs. The respondents were also surveyed to determine what they actually do to enhance the use of ICTs in the activities / functions identified in the value chain. Factors affecting the effective use of ICTs in primary school activities were also identified. Furthermore, barriers to the uptake of ICTs were considered in the survey.

The data collected were analysed using descriptive statistics such as simple percentages, frequency tables, and bar charts. 
Table 1: Information systems that can be used in primary school programmes

\begin{tabular}{|c|c|c|c|c|c|c|c|c|}
\hline Learner enrolment & $\begin{array}{l}\text { Teaching and } \\
\text { learning }\end{array}$ & $\begin{array}{l}\text { Teacher support } \\
\text { and development }\end{array}$ & School infrastructure & $\begin{array}{l}\text { Administration and } \\
\text { management }\end{array}$ & $\begin{array}{l}\text { Access to lessons } \\
\text { \& materials }\end{array}$ & $\begin{array}{l}\text { Teacher } \\
\text { recruitment \& } \\
\text { vacancies }\end{array}$ & Managing funds & Assessment \\
\hline \multicolumn{9}{|c|}{ Activities } \\
\hline $\begin{array}{l}\text { Determine number } \\
\text { of learners to be } \\
\text { enrolled at a } \\
\text { given school } \\
\text { How to register } \\
\text { learners at a } \\
\text { school } \\
\text { Identify learners } \\
\text { who are supposed } \\
\text { to be registered } \\
\text { Identify the } \\
\text { general trend of } \\
\text { enrolment on a } \\
\text { yearly basis } \\
\text { Create a } \\
\text { management plan } \\
\text { (school) } \\
\text { Improve education } \\
\text { awareness in } \\
\text { communities }\end{array}$ & $\begin{array}{l}\text { Schools to come up } \\
\text { with management } \\
\text { plans (monitor } \\
\text { teaching and } \\
\text { learning) } \\
\text { Improved access to } \\
\text { learning materials } \\
\text { Learners being } \\
\text { taught } \\
\text { Provide systematic } \\
\text { review of } \\
\text { performance across } \\
\text { learning areas } \\
\text { Provide better } \\
\text { teaching and } \\
\text { learning } \\
\text { environment } \\
\text { Manage and } \\
\text { implement curricula } \\
\text { in classrooms } \\
\text { Use of ICTs }\end{array}$ & $\begin{array}{l}\text { Develop in- } \\
\text { service training } \\
\text { and support } \\
\text { Identify } \\
\text { knowledge gaps } \\
\text { Reduce workload } \\
\text { Promote } \\
\text { teamwork } \\
\text { Help to } \\
\text { understand } \\
\text { curriculum } \\
\text { Upgrade their } \\
\text { knowledge and } \\
\text { skills to fulfil } \\
\text { their roles }\end{array}$ & $\begin{array}{l}\text { Identify all the } \\
\text { necessary } \\
\text { infrastructure for } \\
\text { effective teaching } \\
\text { and learning } \\
\text { Procure resources } \\
\text { Create a } \\
\text { management plan } \\
\text { Improve security to } \\
\text { protect available } \\
\text { resources }\end{array}$ & $\begin{array}{l}\text { Ensure that lessons } \\
\text { take place } \\
\text { Oversee the } \\
\text { curriculum across } \\
\text { the school } \\
\text { Evaluate learner } \\
\text { performance } \\
\text { Ensure the } \\
\text { availability of } \\
\text { appropriate LTSM } \\
\text { Ensure that heads of } \\
\text { departments (HODs) } \\
\text { monitor the work of } \\
\text { educators } \\
\text { Monitor the work of } \\
\text { HODs } \\
\text { Create class visits } \\
\text { programme and } \\
\text { provide feedback to } \\
\text { educators } \\
\text { Time management }\end{array}$ & $\begin{array}{l}\text { Ensure that } \\
\text { teaching and } \\
\text { learning materials } \\
\text { are available }\end{array}$ & $\begin{array}{l}\text { Ensure that } \\
\text { information about } \\
\text { teachers needed is } \\
\text { readily available } \\
\text { Manage teacher } \\
\text { recruitment }\end{array}$ & $\begin{array}{l}\text { Keep track of } \\
\text { income and } \\
\text { expenditure at } \\
\text { school level } \\
\text { Have an updated } \\
\text { list of debtors } \\
\text { and creditors }\end{array}$ & $\begin{array}{l}\text { Identify } \\
\text { knowledge gaps } \\
\text { Provide systematic } \\
\text { review of } \\
\text { performance } \\
\text { across learning } \\
\text { areas }\end{array}$ \\
\hline \multicolumn{9}{|c|}{ ICTs used } \\
\hline $\begin{array}{l}\text { Enrolment } \\
\text { management } \\
\text { system } \\
\text { Reporting system }\end{array}$ & $\begin{array}{l}\text { School management } \\
\text { system }\end{array}$ & $\begin{array}{l}\text { Performance } \\
\text { monitoring } \\
\text { system }\end{array}$ & $\begin{array}{l}\text { Inventory } \\
\text { management system }\end{array}$ & $\begin{array}{l}\text { School management } \\
\text { system }\end{array}$ & $\begin{array}{l}\text { Inventory } \\
\text { management } \\
\text { system }\end{array}$ & $\begin{array}{l}\text { School } \\
\text { management } \\
\text { system }\end{array}$ & \begin{tabular}{|l} 
Finance \\
management \\
system
\end{tabular} & $\begin{array}{l}\text { Performance } \\
\text { monitoring and } \\
\text { management } \\
\text { system }\end{array}$ \\
\hline
\end{tabular}


Of the 20 schools surveyed, five are public and rural based, seven are private schools in urban areas, and eight are public schools in the urban areas of Gauteng Province (Figure 2). All the public schools surveyed in this study are no-fee-charging schools.

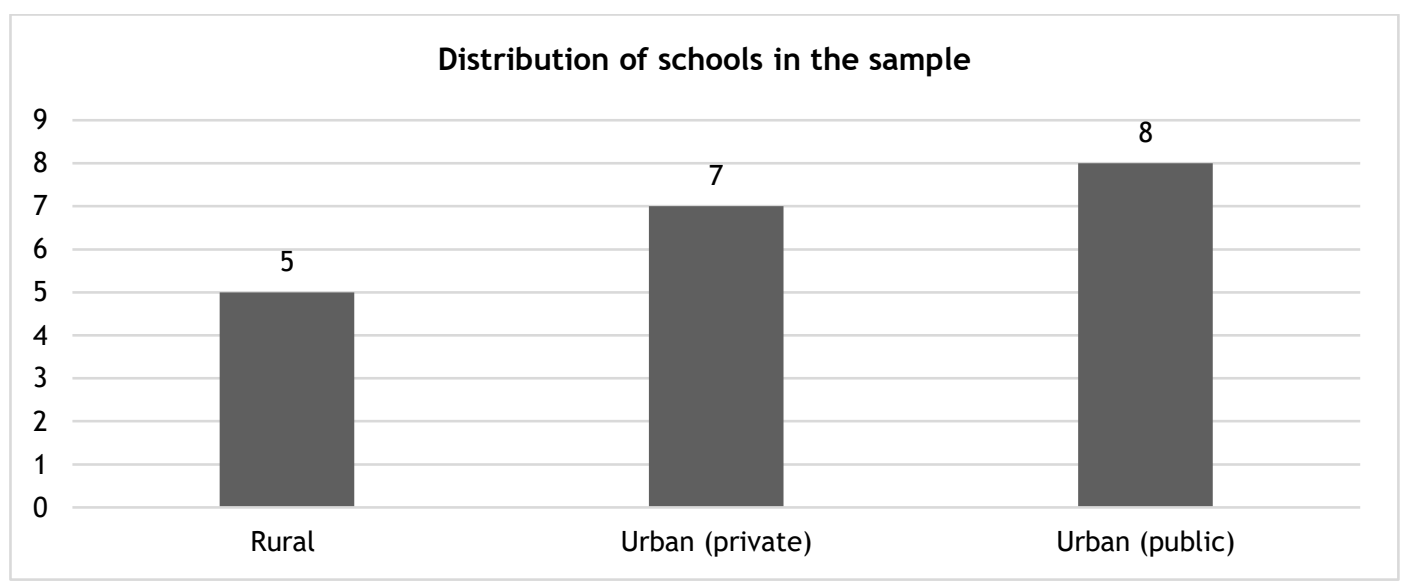

Figure 2: Sample description

The survey showed that there is variation between the rural and urban (private and public) schools in terms of the number of school functions enabled through some forms of ICT. From inspection of the distribution of responses in Figure 3, it can be concluded that private schools tend to apply ICTs in most of the school functions, followed by the public schools in urban areas. Public schools in rural areas seem to be lagging behind in technology use.

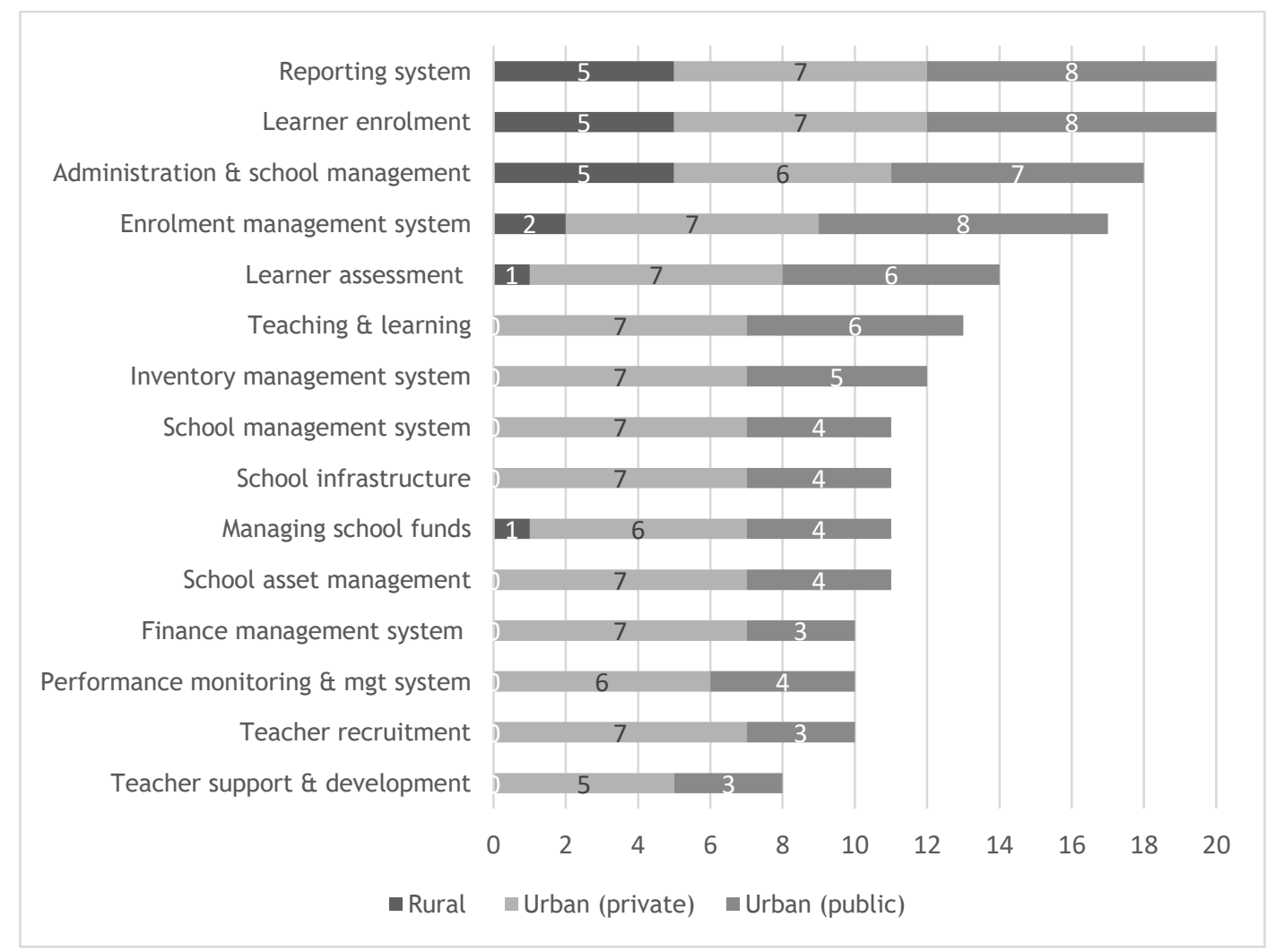

Figure 3: The use of ICTs in school functions 
Through the audit of core school functions, it was found that the use of ICTs is most often implemented in administration, learner enrolment / registration, and reporting systems in all the surveyed schools. This is probably due to the government requirement that all learners need to be electronically enrolled and registered in the government database. However, when compared with urban schools, the surveyed rural schools are not employing ICTs in school functions such as teaching and learning, inventory management, finance management, and asset management. The urban schools (both public and private) are using ICTs in teaching and learning as well as learner assessment. Urban schools seem to lead in ICT use in teacher support and development, performance management and monitoring, and teacher recruitment. All the private schools surveyed are using finance management systems, possibly because they depend on school fees being paid and need to manage their finances in order for the school to be functional.

The survey revealed that the respondents had different experiences of the implementation and use of ICTs in their schools. Figure 5 shows the respondents' views about the perceived use of ICTs in their schools, expressed in counts of responses; while Figure 5 shows the same data in percentages for each respondent group. Several issues were raised by the respondents, with most of the private schools' respondents stating that they were satisfied with the way they were using ICTs in their schools. One respondent from a private school indicated that there seemed to be resistance by users to changing their routines; this may point to a lack of change management processes, or inadequate solutions hindering the adoption process. This is in stark contrast with rural public schools, with only one out of five respondents holding the view that they were satisfied with the way that ICTs were being implemented. All the rural schools surveyed stated that they did not have adequate resources, thus limiting their chances of being more innovative. Also, all the rural public schools surveyed felt that they were neither trained nor equipped with the necessary resources to enhance ICT use in their schools.

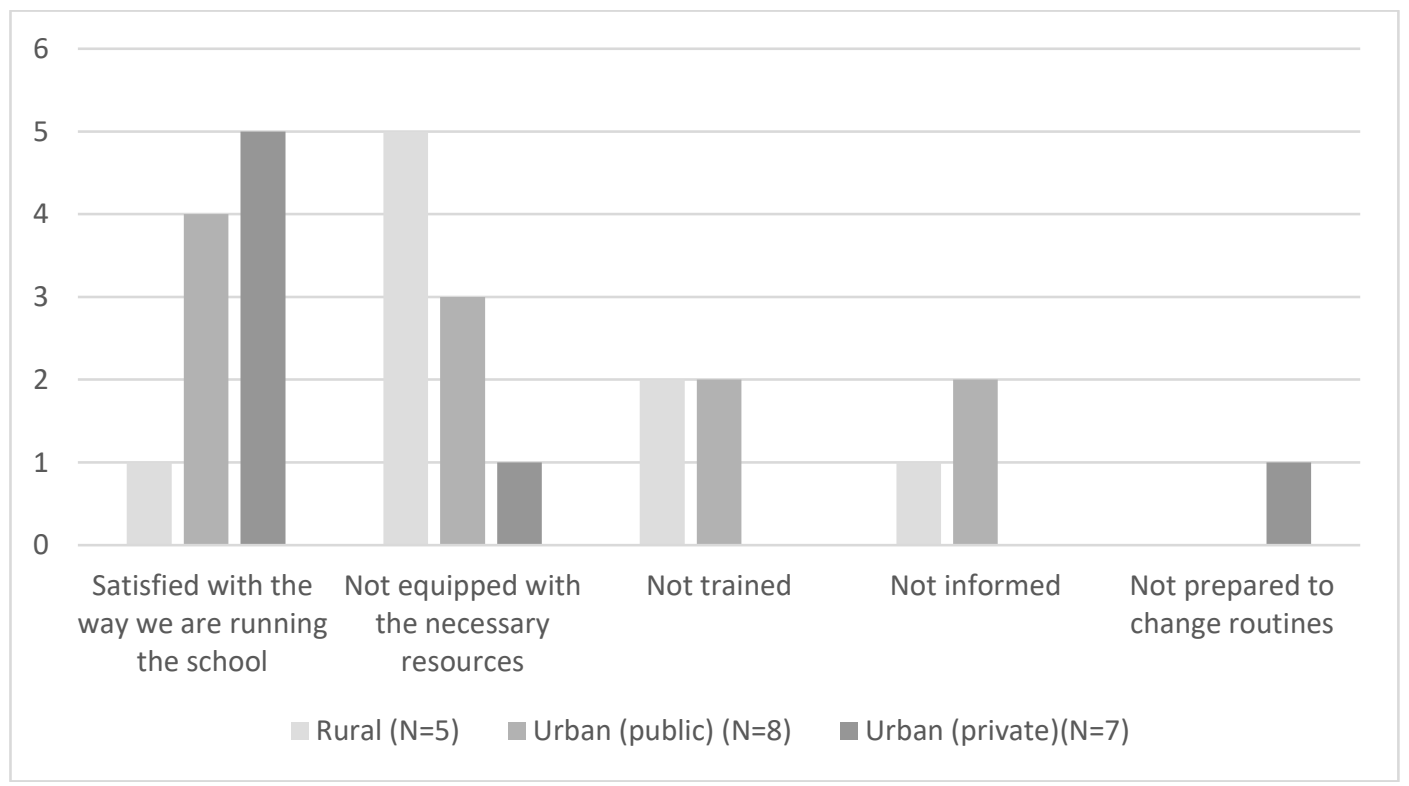

Figure 4: Counts of respondents' views about the reasons for and extent of use of ICTs in their schools $(\mathrm{N}=20)$ 


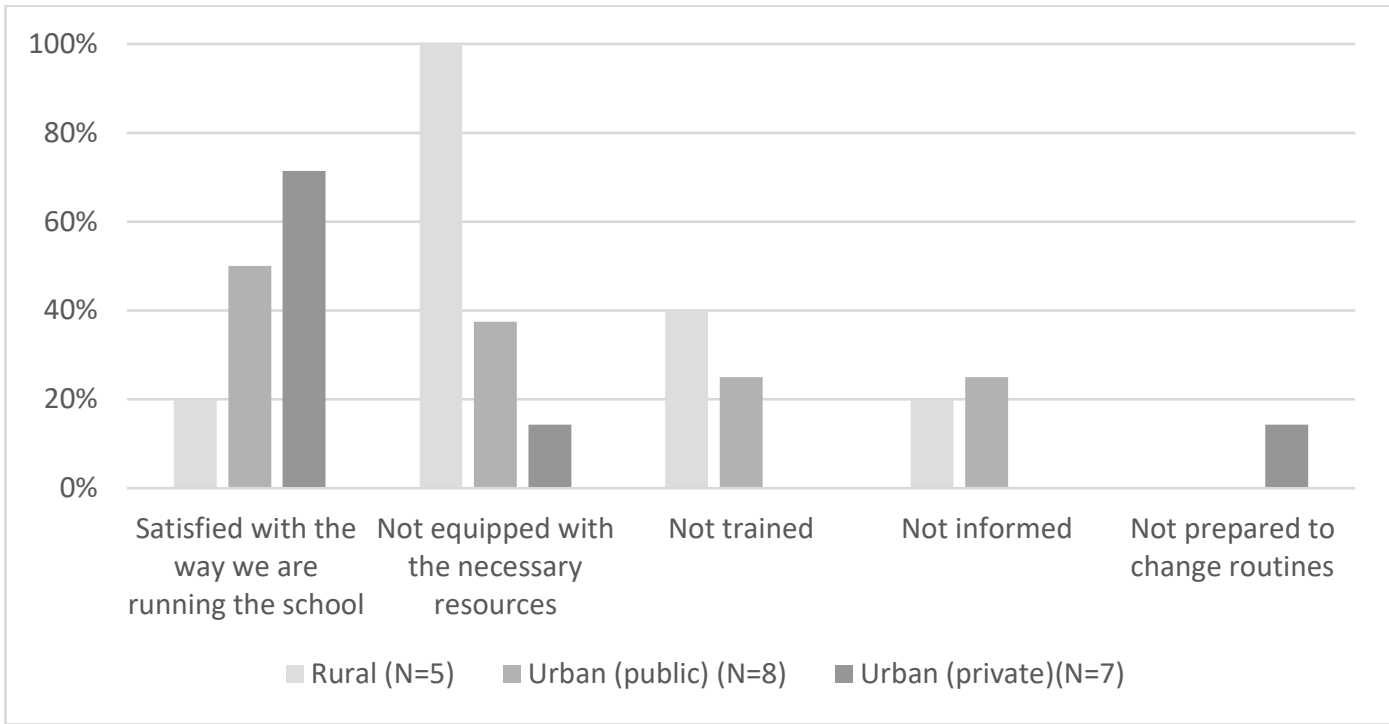

Figure 5: Percentage breakdown (by respondent group) of respondents' views about the reasons for and extent of use of ICTs in their schools $(\mathrm{N}=20)$

Factors affecting the effective use of ICTs - specifically for those programmes for which ICTS were not implemented - were also identified and analysed according to the school type (see Figure 6 for the count and Figure 7 for the percentage breakdown per respondent group). Although all schools were using ICTs in at least one school function, the subjects indicated that the most important barriers to implementing ICTs in their schools were the lack of experts, limited infrastructure, low interest from other stakeholders, inadequate knowledge and training, and lack of funding to implement new technologies properly.

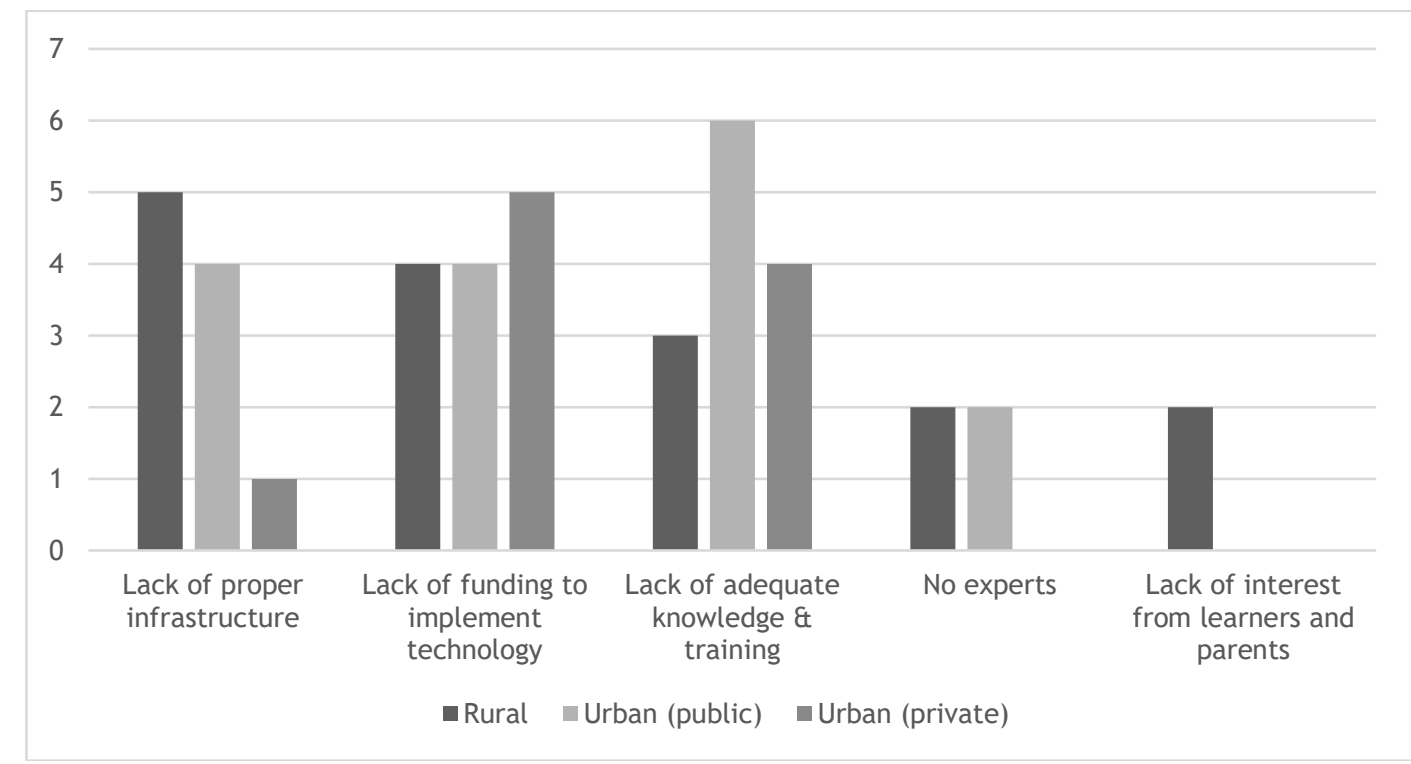

Figure 6: Counts of respondents' views of factors affecting the effective use of ICTs in primary school functions 


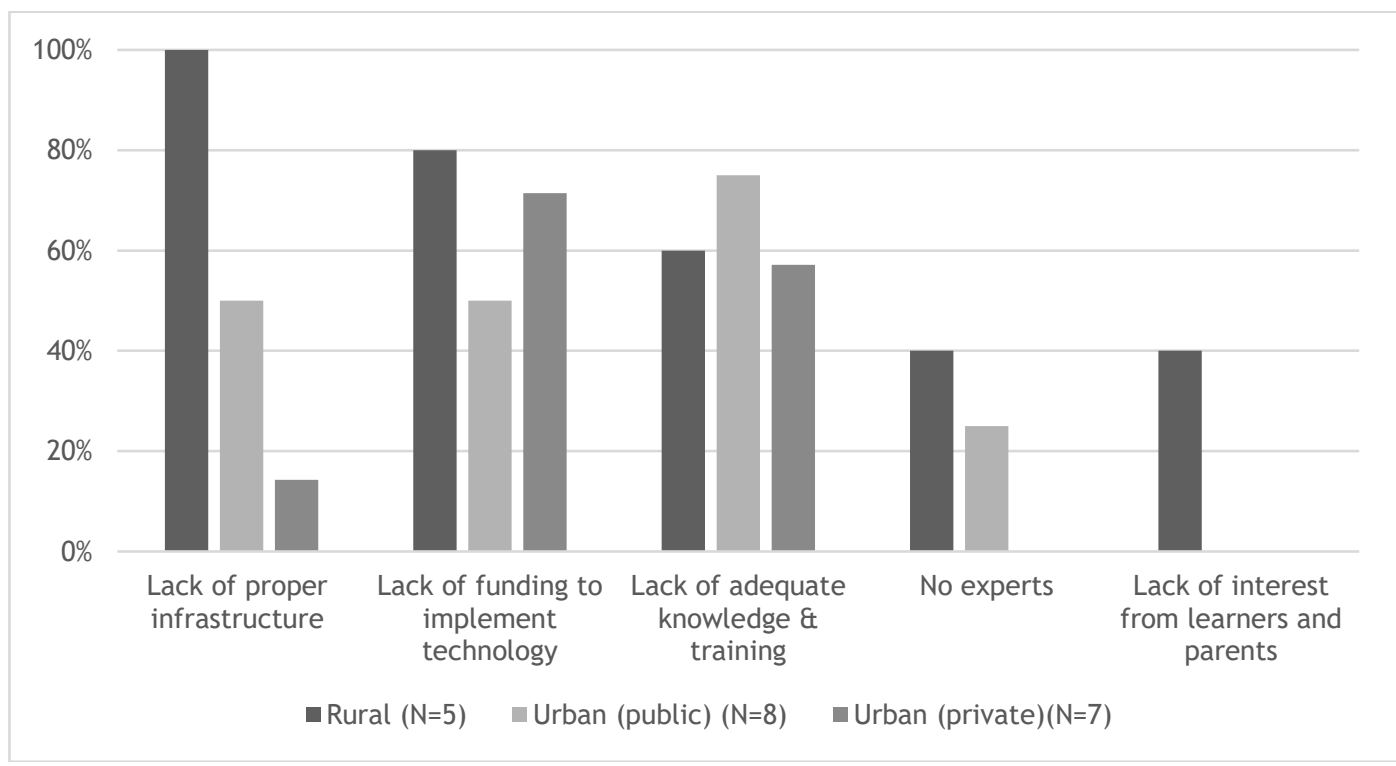

Figure 7: Percentage breakdown (by respondent group) of respondents' views about factors affecting the effective use of ICTs in primary school functions

All the public schools in our sample (all of which are non-fee-paying) are completely dependent on government funding, which seems to hinder the innovative use of technology due to a lack of sufficient resources. Also, in line with the finding that few functions in rural schools are supported by ICTs, these schools are experiencing more barriers to the effective use of ICTs than the schools in urban areas. Rural schools are significantly affected by a lack of proper infrastructure, followed by lack of funding to implement technology, lack of adequate knowledge and training, no access to experts, and lack of interest from learners and parents.

All the public schools reported that they were significantly affected by the lack of infrastructure, funding, and knowledge and training, whereas private schools' main challenge was lack of funding, followed by lack of knowledge and training in some cases. A couple of public schools in the urban areas also indicated that they still had a problem with access to expertise in ICT use. In the same vein, although private schools used ICTs more frequently, they still faced a lack of adequate funding and knowledge and training to use new technology effectively.

The literature reveals that innovations may not succeed if teachers and others staff members are not equipped with the proper skills, the right attitude towards the technology, and the necessary knowledge to take up an innovation [10], [37]. Figure 6 summarises the barriers to proper implementation and use of information and communication technologies in the schools surveyed. In short, this is a reflection on those programmes that do use ICTs in functions. Respondents from the different school types identified barriers to the proper use of ICTs as poor connectivity, high costs and lack of funding, lack of computer skills, and a shortage of resources.

The rural primary schools used ICTs in fewer activities, and had challenges with resources, connectivity, and skills to implement technology effectively. An equal number of urban schools (both private and public) also found resource shortage to be a major challenge. Only the public schools (rural and urban) seemed to be affected by poor connectivity and lack of skills. Four urban schools (one public and three private) indicated that their schools were not experiencing any barriers to the use of ICT tools and technologies in the identified school functions. In conclusion, the shortage of resources proved to be a major challenge to the use of information and communication technologies in the schools surveyed. These resources varied from human capital to proper technological infrastructure. 


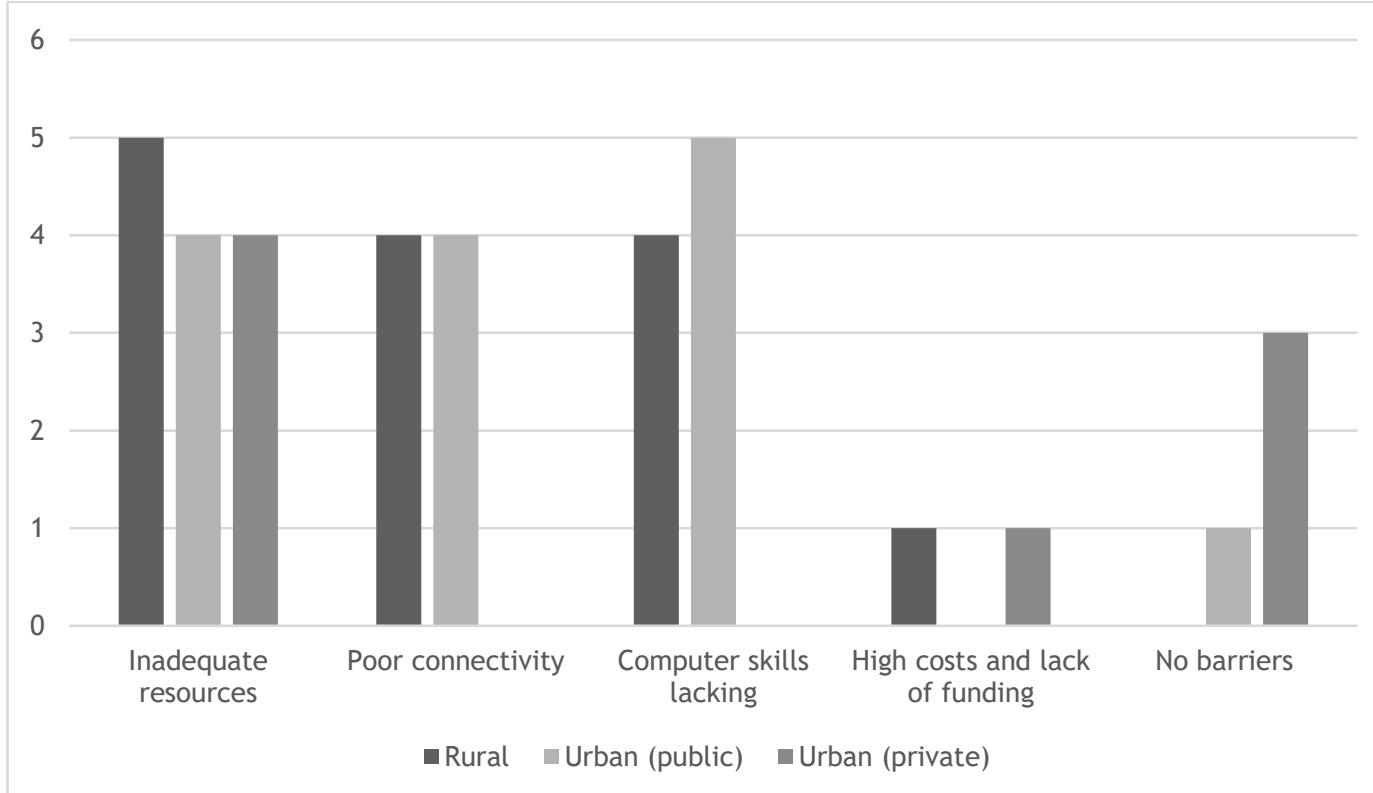

Figure 8: Counts of respondents' views of barriers to the use of ICTs in school management programmes for those in which computer technology is used

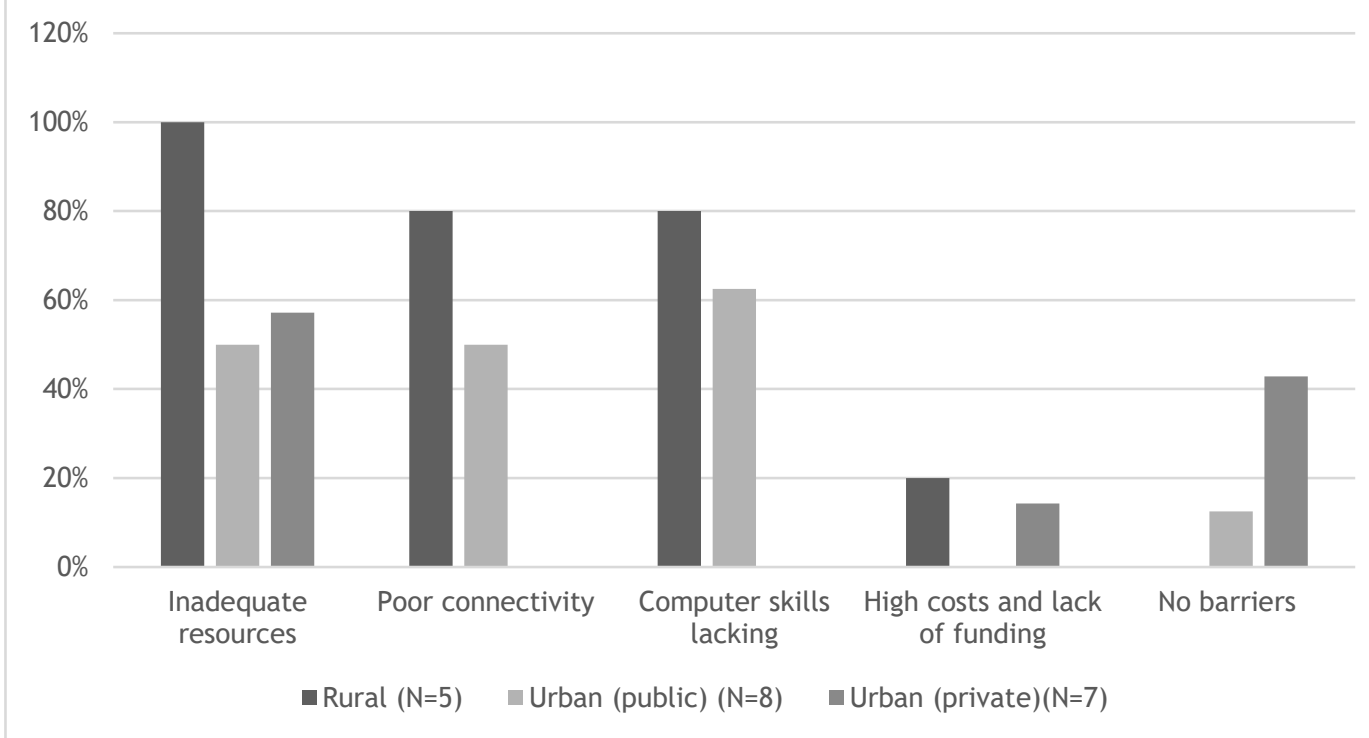

Figure 9: Percentage breakdown (by respondent group) of barriers to ICT use in school functions that use ICTs

Although all the schools surveyed used ICTs for at least one function, there were still several barriers for the schools, resulting in some functions not being supported by ICTs. The two figures below outline the barriers that were outlined by schools for the functions for which ICTs were being used (See Figure 10 and Figure 11). 


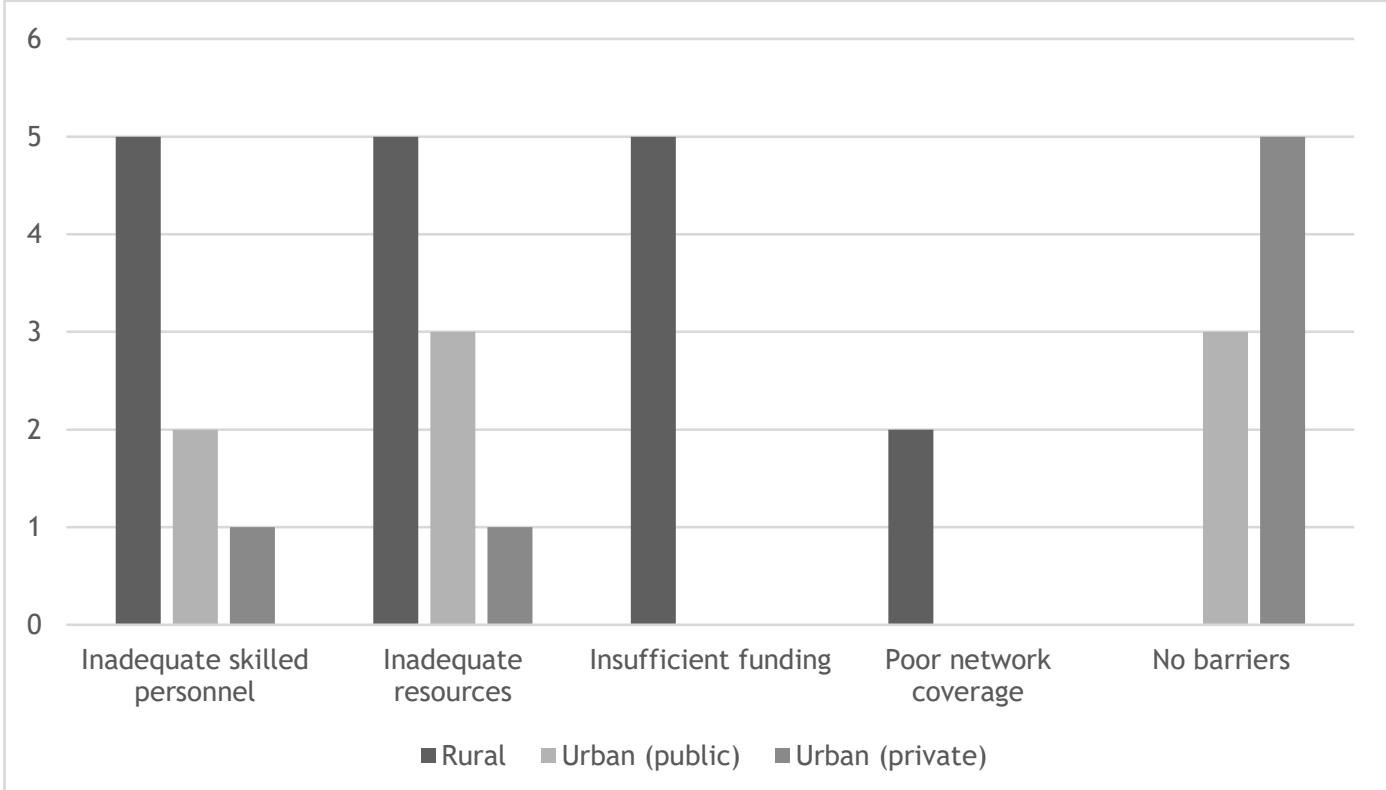

Figure 10: Counts of respondents' views of barriers to ICT use in school functions that do not use ICTs

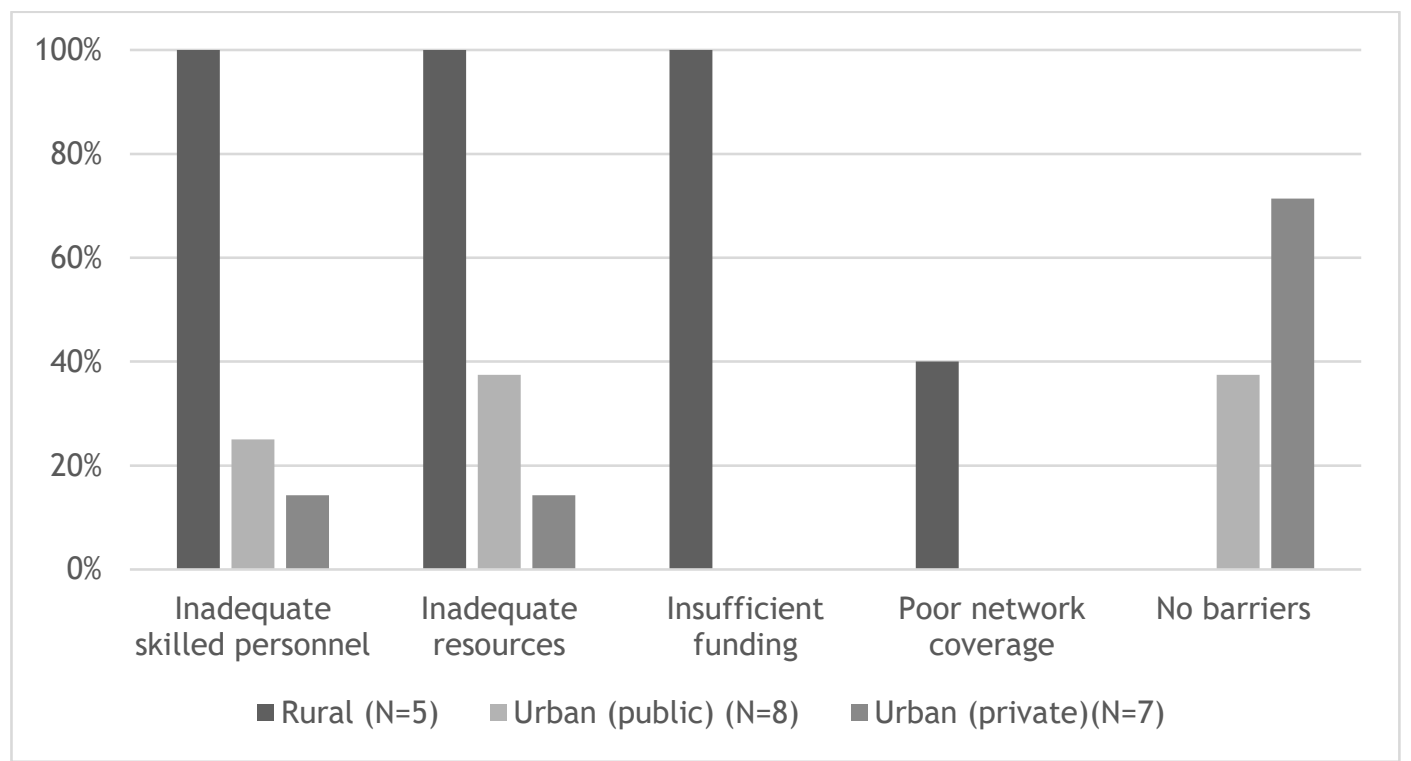

Figure 11: Percentage breakdown (by respondent group) barriers to the programmes that are not using ICTs in their schools

Rural schools that do use ICTs for registration purposes cited barriers most frequently. In a similar way to the previous section, rural schools also identified insufficient funding as a major barrier to the use of ICTs for some school functions. This may be due to lack of government initiatives to employ ICTs, thus not attracting funding from either the government or the private sector. The lack of skilled personnel and the lack of resources, which can be linked to the lack of adequate financial resources, were also considered by the respondents to be major challenges. The barriers identified by the urban schools included inadequately skilled personnel and inadequate resources, while the rural schools experienced insufficient funding and poor network coverage on top of those barriers identified by the urban schools. The rural primary schools' experience of poor network coverage is possibly due to the digital divide between the rural and urban areas of South Africa [38], [39]. 


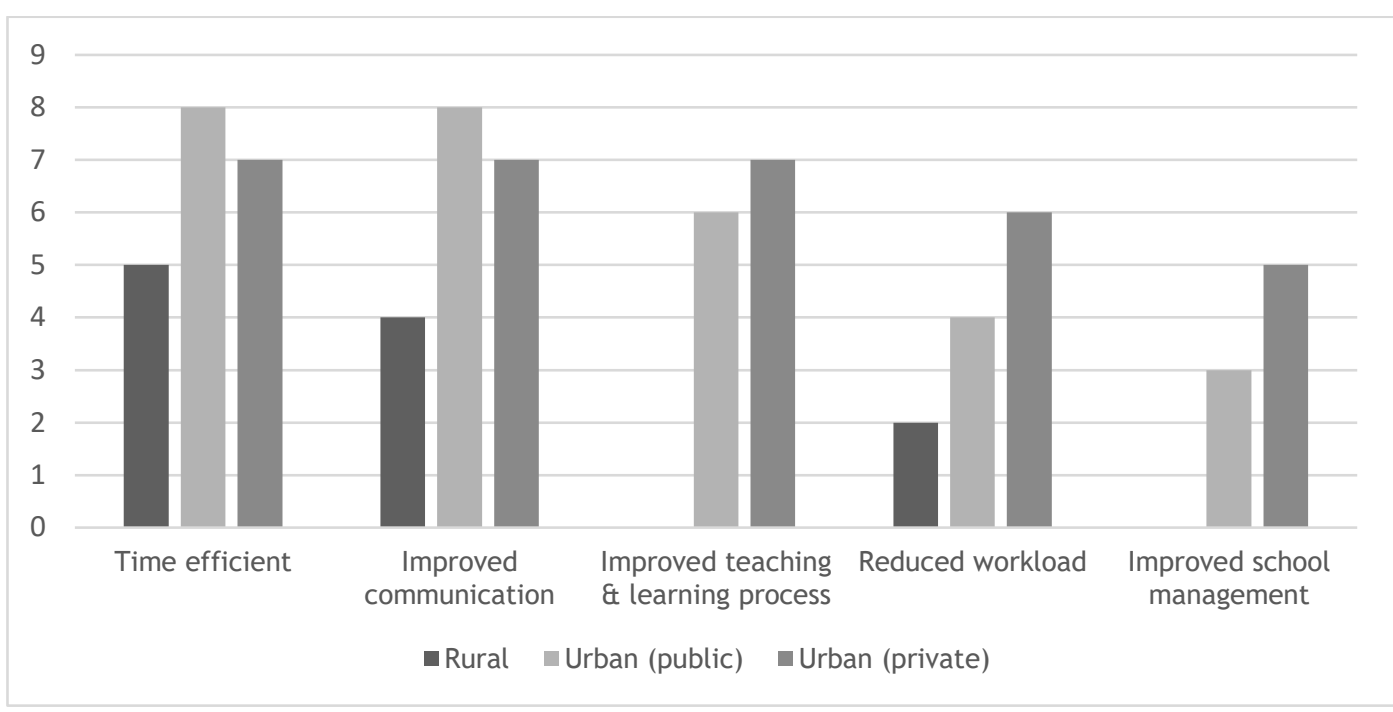

Figure 12: Counts of respondents' views of benefits realised through using ICTs in primary schools

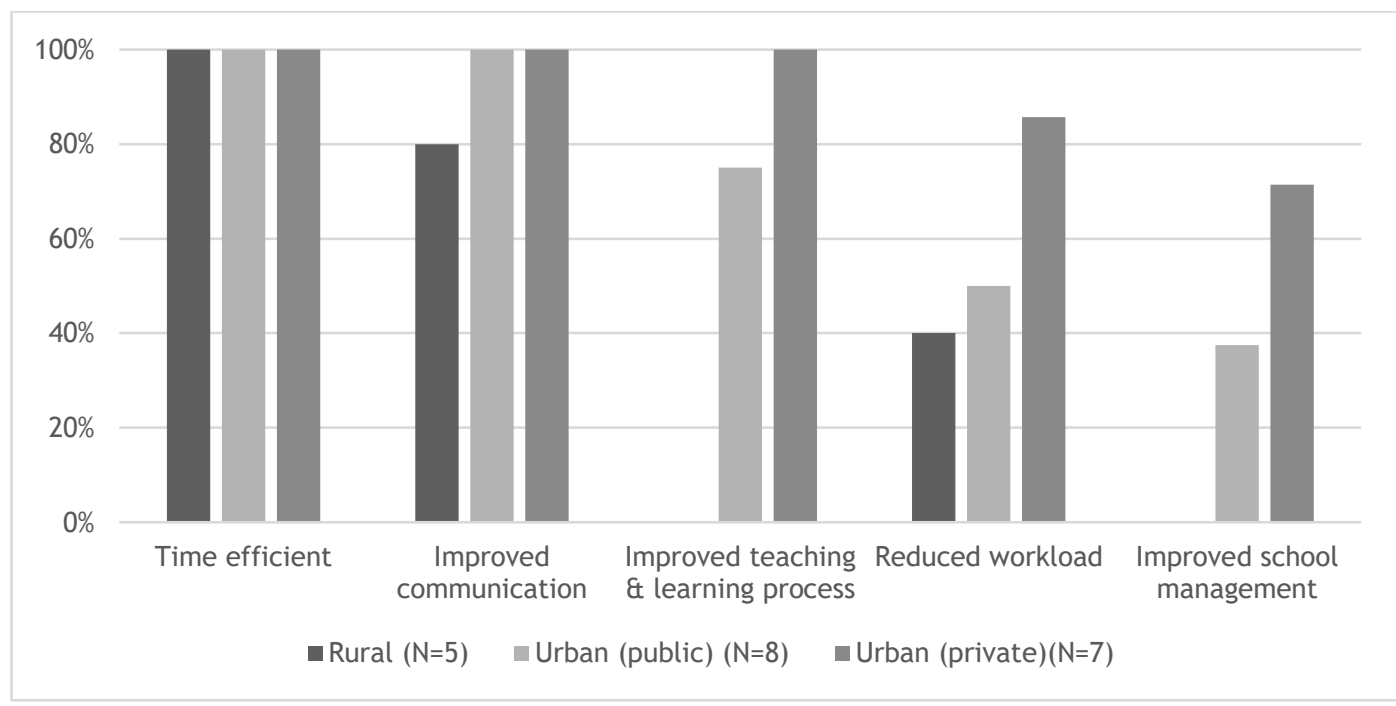

Figure 13: Percentage breakdown (by respondent group) of benefits realised through using ICTs in primary schools

Figure 12 illustrates the perceived benefits of using ICT tools by the respondents surveyed. All the respondents from the 20 schools highlighted that the use of ICTs in school functions aided the implementation of functions in being more time-efficient. For example, when ICTs are employed, less effort is needed to generate the progress reports for all learners if all the marks are captured well; and it is also easier to add or remove a learner or a staff member from the school database. When school activities are automated, it becomes easier to retrieve and update information, which helps the decision-makers to decide on better ways to improve their service to learners.

The use of ICTs is widely recognised as allowing quick and more effective communication with the responsible authorities, using emails that can be accessed regardless of the user's geographical location. All the urban schools identified improved communication as a benefit of the use of ICTs. The respondents also recognised that the use of ICTs in school functions may result in a reduction in workload, with six private schools confirming that they were enjoying that benefit; half of the urban public schools and only two rural schools highlighted this benefit.

ICTs can be said to provide a tool for bringing about educational reforms, thus improving teaching and learning. All the private schools recognised that the use of an innovation may allow for improved teaching and learning. However, most of the public schools did not report this benefit. Only eight schools highlighted that the use of ICTs may result in improved school management, with most of them being private schools. 
The public schools were still not realising such benefits, with only three urban schools enjoying improved management, and none of the rural schools seeming to experience this benefit. Urban schools that used ICTs revealed that they provided a better way of managing the entire school's record-keeping and quick access to information. Thus the use of ICTs allows for easy access and retrieval of information, reducing the time needed to do so.

\section{CONCLUSIONS AND RECOMMENDATIONS}

South Africa is considered to have the most advanced ICT infrastructure in Africa; but there remains a divide between urban and rural communities, as well as between the rich and the poor [40], [41]. Through an audit of the uptake of ICTs in core school functions, the primary data-gathering and analysis process revealed that the implementation and use of ICTs as an innovation to enhance development and improved access to education in primary school is still in its infancy. The researchers concluded that, although South Africa is advanced in ICT use in sectors such as higher education and banking, the primary education sector - and, in particular, public and rural primary schools - may be lagging behind in technology uptake.

Many of the challenges encountered by the public schools can be addressed through government intervention. These schools are dependent on government for funding and for a directive to implement management systems. A key finding is that integrating the ICTs with the existing systems at school level is still a major priority in the uptake of ICTs. There is a need for the Department of Basic Education to drive the implementation of ICTs, and to help address the challenges identified by this study. There is also a need for the government to provide adequate infrastructure for the use of ICTs in primary schools.

Once the right policy and governance frameworks are put in place, ICT uptake is likely to be affected by the adoption process, in which stakeholders need to be aware of the need to adopt technology in their schools. According to the literature reviewed, educational innovations may not succeed if users are not equipped with the necessary skills and knowledge to use innovations [24]. In public schools (rural and urban), the major constraints identified are a lack of adequate knowledge and training, a lack of funding to implement ICTs, and inadequate resources and infrastructure.

Table 2 summarises the challenges and the barriers, as well as the benefits of using ICTs as innovations in primary schools. It shows that the rural schools are still lagging behind in ICT adoption and use.

In order to implement ICTs effectively in primary schools, the following need to be implemented:

- $\quad$ Planning and appropriate support should be put in place for the uptake of ICTs in primary schools. The study identified barriers to the adoption and implementation of the new technologies; so for the ICTs to be fully used, these barriers (for example, skills development, availability to experts, and proper funding) must be considered.

- $\quad$ Rural schools are most likely to be left behind technologically due to the digital divide and a lack of access to appropriate skills and funding. Government should aim to put extra measures in place to ensure that these schools receive help to use technology in performing and managing school functions.

- $\quad$ There is still a need for government to ensure that there is consistent ICT use throughout the primary education system by producing standards, policies, procedures, and processes in order to ensure technology adoption within the system. The government should also initiate ICT projects to attract funding from individuals and private organisations, especially for rural schools, so that disadvantaged learners can also benefit from these life-changing innovations.

- Relevant stakeholders, such as the Department of Basic Education, policy-makers, educators, managers, learners, and parents need to be engaged during the planning, design, and implementation process to ensure that the systems meet the needs of all stakeholders.

- A general awareness of how ICTs can benefit the efficient management of the school enterprise must be promoted at a grassroots level. There is therefore a need to showcase the benefits of ICTs in schools via channels such as social media and television.

- There is also a role for the private sector in this process. For example, private companies can leverage their corporate social responsibility funds to donate computers, train users, and provide funding support for maintaining systems. The private sector can also play a role in developing systems and products that schools can use to manage their functions better. 
Table 2: Summary of the outcomes of various issues reviewed

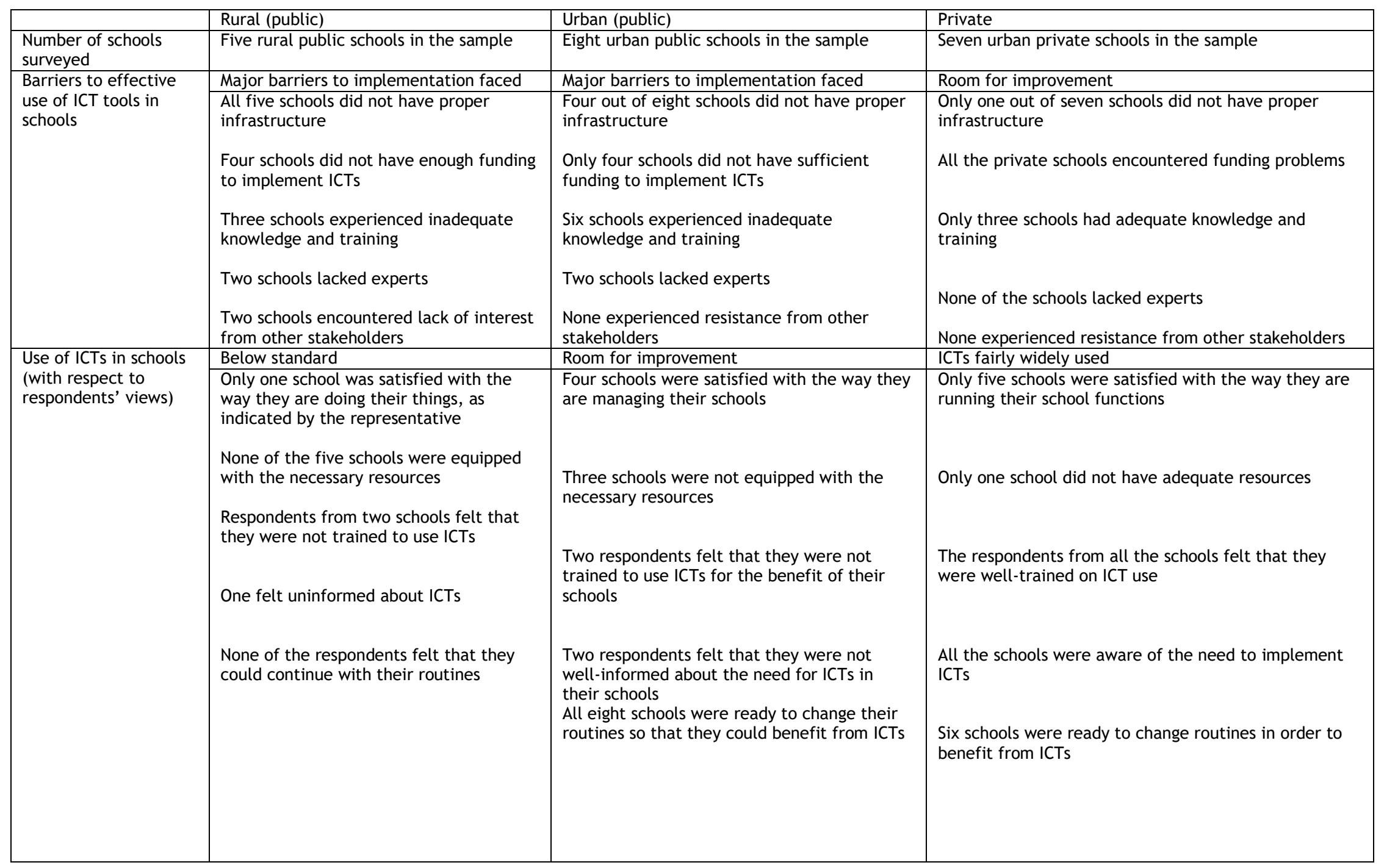




\begin{tabular}{|c|c|c|c|}
\hline & Rural (public) & Urban (public) & Private \\
\hline \multirow{6}{*}{$\begin{array}{l}\text { Barriers to proper } \\
\text { implementation and } \\
\text { use of ICTs } \\
\text { (programmes using } \\
\text { ICTs) }\end{array}$} & Significant room for improvement & Room for improvement & ICTs fairly widely used \\
\hline & $\begin{array}{l}\text { All five schools surveyed encountered } \\
\text { some barriers to ICT use }\end{array}$ & $\begin{array}{l}\text { Seven out of eight schools encountered some } \\
\text { barriers to ICT use }\end{array}$ & $\begin{array}{l}\text { Four out of seven schools experience some barriers to } \\
\text { the use of ICTs }\end{array}$ \\
\hline & $\begin{array}{l}\text { All five schools experienced resource } \\
\text { shortages }\end{array}$ & $\begin{array}{l}\text { Four schools experienced inadequate } \\
\text { resources }\end{array}$ & Four schools experienced inadequate resources \\
\hline & $\begin{array}{l}\text { Four schools were affected by poor } \\
\text { connectivity (digital divide) }\end{array}$ & Four were affected by poor connectivity & None of the schools encountered connection problems \\
\hline & Four schools were affected by a lack of & Five were affected by a lack of skills & All the schools had the necessary skills \\
\hline & computer skills & $\begin{array}{l}\text { None of the schools raised issues about high } \\
\text { costs }\end{array}$ & $\begin{array}{l}\text { One school felt that it was too expensive and that } \\
\text { there was no funding }\end{array}$ \\
\hline \multirow{6}{*}{$\begin{array}{l}\text { Barriers to the use of } \\
\text { ICTs (with respect to } \\
\text { programmes not using } \\
\text { ICTs) }\end{array}$} & Below standard & ICTs fairly widely used & ICTs fairly widely used \\
\hline & $\begin{array}{l}\text { All the surveyed schools had barriers to } \\
\text { ICT use }\end{array}$ & Five schools had some barriers to ICT use & Five schools had no barriers to ICT use \\
\hline & $\begin{array}{l}\text { None of the rural schools had adequately } \\
\text { skilled personnel }\end{array}$ & $\begin{array}{l}\text { Two schools did not have adequately skilled } \\
\text { personnel }\end{array}$ & $\begin{array}{l}\text { Only one school experienced the problem of } \\
\text { inadequately skilled personnel }\end{array}$ \\
\hline & $\begin{array}{l}\text { None of the schools had adequate } \\
\text { resources }\end{array}$ & Three did not have adequate resources & Six schools had adequate resources \\
\hline & $\begin{array}{l}\text { All five schools experienced funding } \\
\text { problems (insufficient funding) }\end{array}$ & $\begin{array}{l}\text { None of the schools raised issues on funding } \\
\text { for this }\end{array}$ & None of the schools raised issues on funding \\
\hline & $\begin{array}{l}\text { Two schools experienced poor network } \\
\text { coverage }\end{array}$ & $\begin{array}{l}\text { None of the schools experienced network } \\
\text { problems }\end{array}$ & None of the schools encountered network problems \\
\hline Benefits & \multicolumn{3}{|l|}{$\begin{array}{l}\text { Reduced workload } \\
\text { Improved communication } \\
\text { Improved school management } \\
\text { Improved teaching and learning processes } \\
\text { Time-efficient }\end{array}$} \\
\hline
\end{tabular}




\section{REFERENCES}

[1] Ainscow, M. 2005. Developing inclusive education systems: What are the levers for change? Journal of Educational Change, 6(2), pp 109-124. https://doi.org/10.1007/s10833-005-1298-4

[2] Ainscow, M. \& Miles, S. 2009. Developing inclusive education systems: How can we move policies forward? Am. Educ. Res. J., (2009), p167-170,

[3] Thijs, A., van Leeuwen, B. \& Zandbergen, M. 2008. Inclusive education in the Netherlands. AN 2.4624.165, SLO, Netherlands institute for curriculum development

[4] UNESCO. 2009. Policy guidelines on inclusion in education. Available at https: //unesdoc.unesco.org/ark:/48223/pf0000177849 (Accessed on 11 May 2020).

[5] SA Government. 1996. National policy on religion and education. Available at https://www.gov.za/documents/national-policy-religion-and-education (Accessed 13 May 2020)

[6] OECD. 2015. PISA 2015: Results in focus. Available at https://www.oecd.org/pisa/pisa-2015-results-in-focus.pdf (Accessed 13 May 2020).

[7] Spaull, N. 2013. Poverty \& privilege: Primary school inequality in South Africa. Int. J. Educ. Dev., 33(5), pp. 436447.

[8] Department of Education. 2004. DoE White Paper 7 on e-Education: Transform, Learn, Teach. Available at https://www.gov.za/sites/default/files/gcis_document/201409/267341.pdf

[9] Pelgrum, W.J. 2001. Obstacles to the integration of ICT in education: Results from a worldwide educational assessment. Comput. Educ., 37(2), 163-178.

[10] Tondeur, J., van Braak, J. \& Valcke, M. 2007. Towards a typology of computer use in primary education. J. Comput. Assist. Learn., 23(3), pp. 197-206.

[11] Karp, M.M., Fletcher, J. 2014. Adopting new technologies for student success: A readiness framework. New York: Teachers College, Community College Research Center, Columbia University

[12] Botha, N. \& Atkins, K. 2005. An assessment of five different theoretical frameworks to study the uptake of innovations. In 2005 NZARES Conference, Nelson, New Zealand.

[13] Rogers, E.M. 1995. Diffusion of innovations. New York: Free Press.

[14] Rogers, E.M., Takegami, S. \& Yin, J. 2001. Lessons learned about technology transfer. Technovation, 21(4), pp. 253-261.

[15] Smeets, E. 2005. Does ICT contribute to powerful learning environments in primary education? Comput. Educ., 44(3), pp. 343-355.

[16] Rogers, E.M. 2003. Diffusion of innovations, New York: Free Press.

[17] Edlmann, F.R.P. \& Grobbelaar, S.S. 2019. The preliminary validation of practices of engagement in innovation platforms: Towards understanding innovation platforms in healthcare. In 2019 IEEE International Conference on Engineering, Technology and Innovation (ICE/ITMC), pp. 1-8.

[18] Dondofema, R.A. \& Grobbelaar, S.S. 2019. Conceptualising innovation platforms through innovation ecosystems perspective. In 2019 IEEE International Conference on Engineering, Technology and Innovation (ICE/ITMC), pp. 110.

[19] Van der Merwe, E. \& Grobbelaar, S.S. 2018. Systemic policy instruments for inclusive innovation systems: Case study of a maternal mHealth project in South Africa. African J. Sci. Technol. Innov. Dev. 10(6), pp. 1-18.

[20] Van der Merwe, E., Grobbelaar, S. \& Bam, W. 2019. Exploring the functional dynamics of innovation for inclusive development innovation systems: A case study of a large scale maternal mHealth project in South Africa. Innov. Dev. 10(1), pp. 117-138.

[21] George, G., McGahan, A.M. \& Prabhu, J. 2012. Innovation for inclusive growth: Towards a theoretical framework and a research agenda. J. Manag. Stud. 49(4), pp. 661-683.

[22] Paunov, C. 2013. Innovation and inclusive development. OECD Science, Technology and Industry Working Papers, No. 2013/01, OECD Publishing, Paris, https://doi.org/10.1787/5k4dd1rvsnjj-en

[23] Grobbelaar, S.S. \& de Wet, G. 2016. Exploring pathways towards an integrated development role: The University of Fort Hare. South African J. High. Educ., 30(1), pp. 1-25.

[24] Grobbelaar, S., Schiller, U. \& de Wet, G. 2016. University-supported inclusive innovation platform: The case of University of Fort Hare. Innov. Dev. 7(2), pp. 249-270.

[25] Porter, M.E. 2001. The value chain and competitive advantage. Understanding Business Processes, London and New York: Routledge

[26] Rathee, R. \& Rajain, P. 2013. Service value chain models in higher education. Int. J. Emerg. Res. Manag. \& Technology, 9359(27), pp. 2278-9359.

[27] Van der Merwe, A., Cronje, J., Rathee, R., Rajain, P. \& Sobotka, B. 2016. Value chain in education sector illustrated with an example. Proc. 2004 Int. Symp. Inf. Commun. Technol. ACM Int. Conf. Proceeding Ser., 90(27), pp. 122-127.

[28] Perumal, P.K. 2013. Study on effective value chain management of public and private schools: Empirical case study from South India. PhD dissertation, Dublin Business School. https://esource.dbs.ie/bitstream/handle/10788/1756/mba_perumal_p-k_2013.pdf?sequence=1 (Accessed 11 May 2020)

[29] Van der Merwe, A. \& Cronje, J. 2004. The educational value chain as a modelling tool in re-engineering efforts. Proc. 2004 Int. Symp. Inf. Commun. Technol. ACM Int. Conf. Proceeding Ser., 90(1), pp. 122-127.

[30] Bush, T., Joubert, R., Kiggundu, E. \& van Rooyen, J. 2010. Managing teaching and learning in South African schools. Int. J. Educ. Dev., 30(2), pp. 162-168. 
[32] Vanderlinde, R., Aesaert, K. \& van Braak, J. 2014. Institutionalised ICT use in primary education: A multilevel analysis. Comput. Educ.,72 (2014), pp. 1-10.

[33] Ndlovu, N.S. \& Lawrence, D. 2012. The quality of ICT use in South African classrooms. Towards Carnegie III, Cape Town, 2012.

[34] Statistics SA. 2001. Investigation into appropriate definitions of urban and rural areas for South Africa. Discussion document. Pretoria: Statistics South Africa (Report No. 01-01-20). Available at http: / /www.statssa.gov.za/?page_id=5134 (Accessed 12 May 2020) .

[35] Government of South Africa. 1996. South African Schools Act. Pretoria. Available at https://www.gov.za/sites/default/files/gcis_document/201409/act84of1996.pdf (accessed 13 May 2020).

[36] Bryman, A. 2012. Social Research Methods: Oxford University Press, Oxford.

[37] Eloff, I. \& Engelbrecht, P. 2002. Implementing inclusive education in South Africa: Teachers' attitudes and experiences. Acta Acad., 34(1), 175-189.

[38] Mutula, S.M. 2008. Digital divide and economic development: Case study of sub-Saharan Africa. Electron. Libr., 26(4), pp. 468-489.

[39] Fuchs, C. \& Horak, E. 2008. Africa and the digital divide. Telemat. Informatics, 25(2), pp. 99-116.

[40] Osunyomi, B.D. \& Grobbelaar, S.S. 2014. Exploring the current and future role of ICTS in HIV/AIDS intervention programs in South Africa. In PICMET 2014 - Portland International Center for Management of Engineering and Technology, Proceedings: Infrastructure and Service Integration. Kanazawa, 2014, pp. 3522-3538.

[41] Osunyomi, B.D. \& Grobbelaar, S.S. 2015. Integrating eHealth in HIV/AIDS intervention programmes in South Africa. SA J. Inf. Manag., 17(1), pp. 1-10. 